\title{
Selection of Poplar Genotypes for Adapting to Climate Change
}

\author{
Marzena Niemczyk ${ }^{1, *}$, ${\text {, Yue } \mathrm{Hu}^{2}(\mathbb{D}) \text { and Barb R. Thomas }}^{2}(\mathbb{D}$ \\ 1 Department of Silviculture and Forest Tree Genetics, Forest Research Institute, Braci Leśnej 3, \\ Sękocin Stary, 05-090 Raszyn, Poland \\ 2 Department of Renewable Resources, 442 Earth Science Building, University of Alberta, \\ Edmonton, AB T6G 2E3, Canada; yhu6@ualberta.ca (Y.H.); bthomas@ualberta.ca (B.R.T.) \\ * Correspondence: M.Niemczyk@ibles.waw.pl; Tel.: +48-22-7150-681
}

Received: 22 October 2019; Accepted: 14 November 2019; Published: 16 November 2019

\begin{abstract}
Deployment of well-adapted, water use efficient, and productive genotypes may be essential for the sustainability of both forests and wood supply for the forest industry, as climate change is increasing water stress around the world. This study aimed to characterize key traits among new genotypes of hybrid poplars (Populus spp.) in water use efficiency (WUE) and evaluate adaptive capacity to guide the selection of appropriate clones/hybrid types for commercial deployment in habitats with an increasing water deficit in northern, continental climates. Forty-five new hybrid poplar genotypes were compared at the age of 10, including two control clones, Walker and Okanese, growing in a common garden genetics trial in northern Alberta. We studied the relationships between their productivity and WUE, photosynthetic assimilation, transpiration, stomatal conductance, stomatal density and length, and leaf size and weight. In addition, the genetic variance and heritabilities of physiological and morphological characteristics related to WUE were calculated. Results of this study revealed that most of the clones showed an adaptive capacity to acclimatize (small and dense stomata) to the region of deployment. Morphological traits were characterized by higher heritabilities than physiological traits. Hybrids between Populus balsamifera and Populus maximowiczii species showed a slightly greater adaptive potential to the area of our study than the other tested cross types. Walker, a clone widely planted across the Canadian prairies, showed inferior WUE and productivity in comparison to the new genotypes tested. Selection and tree breeding for adaptation to climate change in the region of our investigation identified highly productive genotypes with dense, small stomata and a larger leaf area to dry mass ratio. As these traits are heritable, selection of clones with these traits will ensure a faster reaction of stomata when faced with a water deficit. The low genetic effect, heritability estimates, and high residual effect for physiological traits, impose a severe limitation on the use of gas exchange measurements under field conditions in tree improvement programs selecting for drought resistance.
\end{abstract}

Keywords: hybrid poplar; water use efficiency; climate change; stomatal density; stomatal conductance; Walker; tree breeding

\section{Introduction}

Climate change is increasing water stress in many areas of the world as a result of increasing temperatures and evapotranspiration, and more frequent episodes of climatic anomalies such as drought events [1]. Water availability, in particular, is considered the main environmental factor limiting tree growth and productivity worldwide [2]. Since 2001, in western Canada, climatic conditions have been significantly drier, leading to widespread impacts on the forests [3]. The analyses of the Climate Moisture Index (CMI) and the Palmer Drought Severity Index (PDSI) for the Canadian boreal zone 
suggest that the combined changes in precipitation and temperature will lead to an increase in drier conditions in the boreal forest region of western Canada [4]. Therefore, the deployment of well-adapted, water use efficient, and productive genotypes may be essential for the sustainability of both forests and wood supply for the forest industry.

The Populus genus is of great economic importance for forestry in the northern hemisphere and especially in temperate and boreal ecosystems [5]. Poplars (Populus spp.) belong to tree species with the highest assimilation capacity among woody plants, reaching up to $15-25 \mathrm{mg} \mathrm{CO}_{2} \mathrm{dm}^{-2} \mathrm{~h}^{-1}$ [6], which makes them attractive and useful for domestication. Poplar breeders use widely different approaches and technologies that range from traditional hybridization for cultivar development to molecular investigations into the structure of the genome [7]. Hybridization in poplars enables tree breeders to bring together and combine the wanted traits of different species, to capitalize on hybrid vigour (heterosis) [8,9]. Generally, the greater the genetic diversity of the parents, the higher the level of heterosis achieved, although it should be mentioned that very diverse parental lines do not always make the best hybrids [10]. The general magnitude in growth and biomass production in hybrids can be described by the manifestation of multigenic heterosis in terms of energy-use efficiency. As trees (and other plants) take light energy as input to assimilate basic elements into biomass, hybrids can have more efficient growth than inbred plants because of the significant reduction in the energy-consuming processes of protein metabolism possibly due to the higher genetic diversity [10]. Such an effective mechanism in terms of water use consumption can be key for plants to thrive under more arid conditions in the face of climate change.

The term "water use efficiency" (WUE) has long been used in physiological research related to the economics of plant production in relation to water consumption [11], and can be measured at different scales, ranging from instantaneous measurements at the leaf level to more integrative scales at the plant (e.g., wood cores, $\mathrm{C}^{13}$ ) and ecosystem levels [2,12,13]. Most studies of WUE are performed on the basis of leaf photosynthesis (carbon gained in photosynthesis $(\mathrm{A})$ ) in relation to water lost in transpiration (E) or to stomatal conductance $\left(g_{s}\right)$, which permits the calculation of instantaneous WUEleaf $(A / E)$ or intrinsic WUEi $\left(\mathrm{A} / \mathrm{g}_{\mathrm{s}}\right)[2,13]$. Selection and breeding to enhance WUE can be important, particularly for poplars, as they require large amounts of water in general and are characterized by strong transpiration rates $[6,11]$.

As productivity of fast-growing hybrid poplars is highly dependent on water availability [14-16], inter- and intraspecific differences in WUE among poplar hybrids have been studied extensively [16-21]. The reported variation in response suggests that WUE at the leaf level can potentially be used as a trait to target in tree improvement breeding programs. WUE could be improved by an incremental increase in leaf photosynthesis, or by a reduction in stomatal conductance or transpiration rate [2]. Consequently, selection focused on WUE at the leaf level may not be associated with higher productivity and in accordance with factors influencing WUE-photosynthesis or transpiration/stomatal conductance [16,22]. The lack of such a consistent relationship suggests that WUE is mainly controlled by stomatal conductance, whereas a positive relationship between productivity and WUE indicates that control is through photosynthetic capacity [12,16]. Therefore, it has been suggested that the use of WUE for selection should be coupled with additional and less ambiguous traits that can be associated with productivity, such as leaf area, stomatal density, and size [16,23,24].

Traits such as stomatal density, aperture, and their associated regulation are of key interest in the study of drought-adaptation to semi-arid conditions [20]. Stomatal characteristics, including size and density, vary widely among poplar genotypes and species $[25,26]$ and, together with stomatal response, show evidence of adaptive acclimation [20]. It has been shown that stomatal size is smaller, stomatal density is greater, and stomatal control more sensitive in more xeric environments [27].

Most experimental studies examining WUE at the leaf level across different hybrid poplar genotypes have focused on the early stage of tree growth, and they are most often carried out under greenhouse conditions $[16,17,21]$. There may, however, be important differences in how different life stages of trees respond to environmental conditions and how particular hybrids and genotypes adapt to 
environmental conditions in a region of future deployment. To our knowledge, these studies have not been carried out extensively. Thus, we used hybrids of P. maximowiczii, P. balsamifera, Populus nigra, and Populus deltoides, selected and bred in the humid continental climate of Quebec, and tested them in the more xeric climatic condition of northern Alberta (Canada). At age 10, we further selected families and clones within families among different productivity groups (high, average, and low based on volume) growing in a large common garden genetics trial to study: (1) The relationships (possible trade-offs) between productivity and WUE, photosynthetic assimilation, transpiration, stomatal conductance, stomatal density and length of stomatal guard cells, and leaf size and leaf weight; and (2) to estimate the genetic variance and heritabilities of physiological and morphological characteristics related to WUE. This research may help to characterize (heritable) key traits in WUE, and therefore allow us to evaluate adaptive capacity (including small and dense stomata) to guide selection of appropriate clones/hybrid types for commercial deployment in habitats with increasing water deficit in northern, continental climates.

\section{Materials and Methods}

\subsection{Plant Material and Study Design}

The experimental area of the study was established in the proximity of the Alberta-Pacific

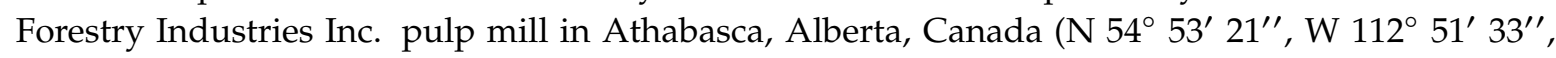
$575 \mathrm{~m}$ a.s.l.). Average annual temperature for the last 10 years (2008-2017) was $2.2^{\circ} \mathrm{C}$, with a mean annual precipitation of $432 \mathrm{~mm}$ [28].

In spring 2008, over-winter dormant stock, rooted from cuttings the previous summer in a commercial greenhouse, were planted. Tree spacing was $2.5 \times 2.5 \mathrm{~m}$ with a single tree row of excess hybrid poplars established around the trial as a buffer. The study design was a single-tree plot with four replicates of each clone across the four blocks. The trial contained hybrids of species from the Aigeiros and Tacamahaca sections that were bred in Quebec and consisted of 1978 hybrid poplar clones from 63 families (for more information, see [29]). At the age of 10 years, based on measurements of diameter at breast height $(\mathrm{DBH})$ and tree height $(\mathrm{H})$, volume of the trees $(\mathrm{V})$ was calculated. For the evaluation of physiological and morphological traits, nine families with contrasting productivity were selected. These families were then categorized into high volume, average volume, or low volume groups. A subset of families comprised of five clones each was selected. Due to no replication (low survival rate) for two clones (AP 4469 -12; AP 4507 -4), we decided to exclude them from the analyses. Two related poplar clones planted widely across the prairies, female clone Walker (P. deltoides $\times($ Populus laurifolia $\times$ P. nigra) $)$ [30] and a male progeny of Walker called Okanese $($ Walker $\times(P$. laurifolia $\times P$. nigra $))$ [31], were used as reference clones. In total, 45 clones were selected for detailed measurements of physiological and morphological traits (Table 1).

Table 1. Detailed information of 45 selected hybrid poplar clones, including productivity ranking based on volume, female and male parentage, cross type, family codes, and clone numbers, where P. refers to Populus.

\begin{tabular}{|c|c|c|c|c|c|}
\hline Productivity Group & Female Parent & Male Parent & Cross Type & $\begin{array}{l}\text { Family } \\
\text { Codes }\end{array}$ & Clone Numbers \\
\hline \multirow{3}{*}{ high } & P. balsamifera & P. maximowiczii & $\mathrm{B} \times \mathrm{M}$ & 4465 & $\begin{array}{c}\mathrm{AP} 4465 \text {-8; AP } 4465 \text {-14; AP } 4465 \text {-15; } \\
\text { AP } 4465 \text { - } 16 \text {; AP } 4465-17\end{array}$ \\
\hline & & & & 4485 & $\begin{array}{c}\mathrm{AP} 4485-1 ; \mathrm{AP} 4485-2 ; \mathrm{AP} 4485-3 ; \mathrm{AP} \\
4485-4 ; \mathrm{AP} 4485-5\end{array}$ \\
\hline & P. maximowiczii & P. balsamifera & $\mathrm{M} \times \mathrm{B}$ & 4491 & $\begin{array}{c}\mathrm{AP} 4491 \text {-2; } \mathrm{AP} 4491-3 ; \mathrm{AP} 4491-4 ; \mathrm{AP} \\
4491-5 ; \mathrm{AP} 4491-8\end{array}$ \\
\hline \multirow{3}{*}{ average } & P. balsamifera & P. maximowiczii & $\mathrm{B} \times \mathrm{M}$ & 4460 & $\begin{array}{c}\mathrm{AP} 4460 \text {-6; AP } 4460 \text {-13; AP } 4460 \text {-14; } \\
\text { AP } 4460 \text {-18; AP } 4460-20\end{array}$ \\
\hline & & & & 4463 & $\begin{array}{c}\mathrm{AP} 4463-2 ; \mathrm{AP} 4463-5 ; \mathrm{AP} 4463-8 ; \mathrm{AP} \\
4463-9 ; \mathrm{AP} 4463-14\end{array}$ \\
\hline & P. maximowiczii & P. balsamifera & $\mathrm{M} \times \mathrm{B}$ & 4469 & $\begin{array}{c}\text { AP } 4469 \text {-4; AP } 4469-11 ; \text { AP } 4469-15 ; \\
\text { AP } 4469 \text {-16; }\end{array}$ \\
\hline
\end{tabular}


Table 1. Cont.

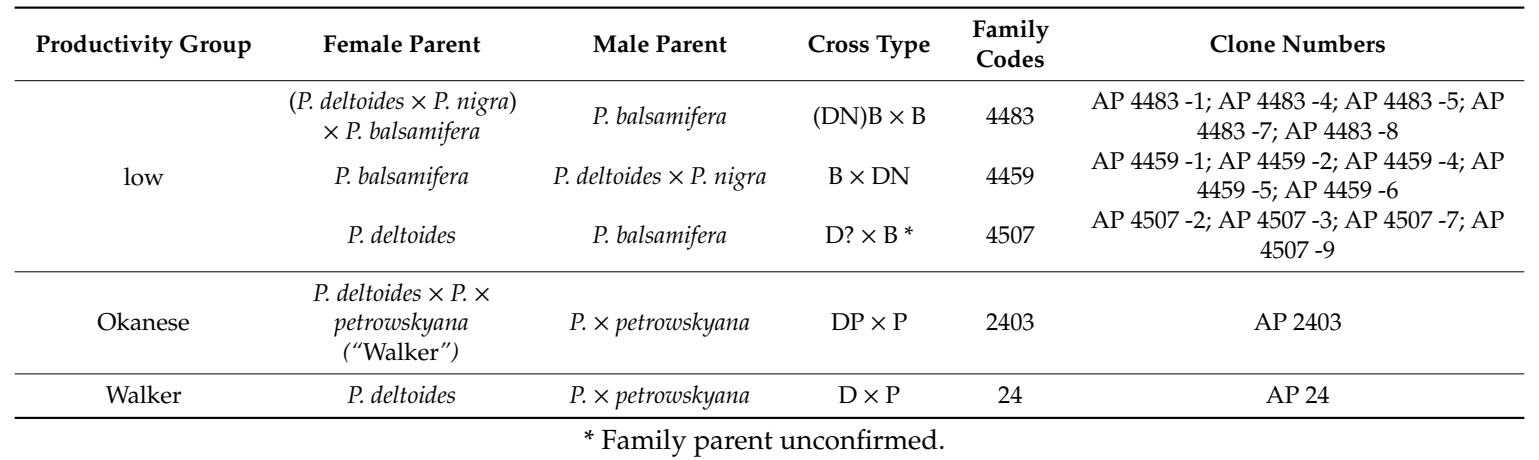

\subsection{Measurement of Gas Exchange Parameters}

Measurements of gas exchange parameters were recorded in June 2018, under field conditions on all ramets of selected clones within families from different productivity groups. Net photosynthetic rate $(\mathrm{A})$, stomatal conductance $\left(\mathrm{g}_{\mathrm{s}}\right)$, instantaneous WUE (WUEleaf), transpiration (E), and vapor pressure deficit (VPD) were measured using a portable infrared gas exchange system (IRGA) (CIRAS-3, PP Systems, Amesbury, MA, USA). Additionally, WUEi (intrinsic water use efficiency) was calculated as a ratio of $\mathrm{A} / \mathrm{g}_{\mathrm{s}}$. As the WUEleaf and WUEi were highly correlated $(r=0.83, p<0.05)$, we limited further analysis to WUEi. The measurements of gas exchange parameters were made during the day, on a sun-exposed leaf from a branch on the south side of the crown. Due to the height of the crown, it was necessary to remove a branch from each tree in order to access the sun-exposed leaves. Branches were taken from approximately a $6 \mathrm{~m}$ height using a pole pruner. The size of the branch was about $100 \mathrm{~cm}$ long, which allowed us to achieve stable conditions during measurement. All leaves measured had identical conditions during the processing of the samples, and branches were removed sequentially as we moved from tree to tree. Branches were never left from more than $1 \mathrm{~min}$ prior to initiation of taking the measurements. To mitigate the potential bias in measurements during the day, the exact time of gas exchange for each measurement was recorded and then calculated as an hour after sunrise (HAS), and considered in the model as a covariate (see subchapter 2.4 Statistical Analyses). Measurements were taken with a fixed $\mathrm{CO}_{2}$ level set at $390 \mathrm{ppm}$, a saturating light level PAR (photosynthetic active radiation) of $1000 \mu \mathrm{mol} \mathrm{m}^{-2} \mathrm{~s}^{-1}$, an ambient temperature of $27^{\circ} \mathrm{C}$, and relative humidity of approximately $40-50 \%$.

\subsection{Measurement of Morphological Characteristics}

Five additional leaves were collected from each tree from the same branch harvested above. Collected leaves were put into plastic bags and transported to the University of Alberta within 48 hours in a cooler with icepacks, where they were then stored in a fridge until measurements were taken (within two weeks). The leaf area of all five leaves was measured using an $\mathrm{Li}-3100 \mathrm{C}$ area meter (LI-COR ${ }^{\circledR}$ Biosciences Lincoln, NE, USA). One leaf from each tree was then used to determine stomatal density and length, and the remaining four leaves where oven-dried at $70{ }^{\circ} \mathrm{C}$ until their weights stabilized. On the basis of leaf area (LA) and dry mass (DM), the specific leaf area (SLA) was calculated for each sample as follows:

$$
\text { SLA }\left[\mathrm{cm}^{2} \mathrm{~g}^{-1}\right]=\text { LA }\left[\mathrm{cm}^{2}\right] / \mathrm{DM}[\mathrm{g}]
$$

The microrelief (replica) method was used to assess stomatal density (SD) [32]. Impressions of the abaxial (lower) epidermis were taken using colorless nail polish. All replica impressions were fixed onto glass microscope slides and examined and photographed under a light microscope (Zeiss Microscope Primo Star with internal HD camera, Jena, Thuringia, Germany) at 10x magnification. A minimum of three pictures were taken randomly of each leaf and scaled up to the total number of stomata per $1 \mathrm{~mm}^{2}$. The microscope pictures were analyzed by StomataCounter (https://stomata.uvm.edu; accessed on 
18 October 2018), an automated stomata counting system using a deep convolutional neural network to identify stomata [33]. Each microscopic image was analyzed individually to avoid mistakes in stomata identification, and human counting was applied when needed by using the "Annotate from automatic" annotation mode. The length of guard cells was measured using digiShape software (ver. 1.9.19, Cortex Nova, Bydgoszcz, Poland). The length of 30 abaxial stomata (SL) was measured for each leaf from all ramets of selected clones.

\subsection{Statistical Analyses}

The relationships between physiological and morphological traits and tree productivity were tested using Pearson correlation coefficients. To further explore variation and bring out patterns in the data set, a principal component analysis (PCA) was employed. The multidimensional space was reduced to eigenvectors (the principal components) that corresponded to the eigenvalues retaining the most important variances. In our analysis, the eigenvectors were computed on the basis of the constructed correlation matrix.

To assess differences and genetic effects in water use for physiological and morphological characteristics (as dependent variables), a linear mixed model was applied. In the preliminary analysis, we considered a full linear model with families, clones within families, blocks, interaction between families and blocks (as random effects), productivity groups and cross types (as fixed effects). Additionally, two covariates were taken into account for analysis of the gas exchange measurements (physiological traits): VPD and HAS. Since the study design did not allow us to assess the simultaneous effects for productivity groups and cross types (in most cases, particular crosses were assigned to specific productivity groups), we further considered the productivity as a fixed effect alone. Moreover, due to the irrelevance of the HAS for gas exchange measurements, it was removed from the final model. Ultimately, the reduced models were implemented as follows:

$$
y_{i j k}=\mu+f_{i}+c_{i j}+b_{k}+I_{i k}+P+V P D+e_{i j k}
$$

where $y_{i j k l}$ is the response measured by the kth ramet of the jth clone within the ith family, $\mu$ is the overall mean, $f_{i}$ is the random effect of the family $i, c_{i j}$ is the random effect of clone $j$ nested in family $i$, $b_{k}$ is the random effect of block $k, I_{i k}$ is the random interaction effect of family $i$ with block $k, \mathrm{P}$ is the fixed effect of productivity group (high, average, low, Walker and Okanese), VPD is a covariate effect included in the model for physiological traits only, and $e_{i j k}$ is the random error in block $k$ on clone $j$ within family $i$. The significance of fixed and covariate effects was tested with F-tests, followed by their $p$-values. The post-hoc comparisons between productivity groups were performed using a least significant difference (LSD) test. Z-tests followed by their $p$-values were carried out to determine where random effects were significantly different from zero.

The variance components were estimated using the restricted maximum likelihood (REML) procedure [34,35]. The broad-sense heritability (repeatability) $\mathrm{H}^{2}$ was calculated using the following function:

$$
H^{2}=\frac{V_{G}}{V_{P}}=\frac{\sigma_{f}^{2}+\sigma_{c}^{2}}{\sigma_{f}^{2}+\sigma_{c}^{2}+\sigma_{l}^{2}+\sigma_{e}^{2}}
$$

where $V_{G}$-genetic variance, $V_{P}$-phenotypic variance, $\sigma_{f}^{2}$-variance of family effects, $\sigma_{c}^{2}$-variance of clone within family effects, $\sigma_{l}^{2}$-variance of family-by-block interaction effects, and $\sigma_{e}^{2}$-variance of residual effects. All statistical analyses were performed with Statistica 13.1 statistical package (StatSoft Inc. Tulsa, OK, USA). 


\section{Results}

\subsection{Relationships between Traits}

Table 2 summarizes the mean values, coefficients of variation $(\mathrm{CV} \%)$, and the correlation coefficients between the studied traits, along with their significance at the level of $\alpha=0.05$. The mean value for WUEi was $5.51 \mathrm{mmol} \mathrm{CO} \mathrm{mol}^{-1} \mathrm{H}_{2} \mathrm{O}$, and was characterized by a coefficient of variation of $22 \%$. Stomatal conductance $\left(\mathrm{g}_{\mathrm{s}}\right)$ was the most variable trait among physiological characteristics measured (mean $=291.66 ; C V=26 \%$ ), while among morphological traits, LA and DM were characterized by the highest variability $(\mathrm{CV} \approx 28 \%$ ). The Pearson correlation coefficients showed that stomatal conductance correlated with most of the other traits (physiological and morphological). Negative correlations were found for $g_{s}$ with WUEi, SD, V, SLA, and LA, while positive correlations were found with $E$ and A. WUEi was significantly and negatively correlated with E (-0.79) and, as mentioned, with $g_{s}(-0.75)$. Specific leaf area was the only morphological trait that correlated with WUEi (0.35). Volume was also positively correlated with morphological traits: LA, SLA, and DM. The SL was the only trait that failed to correlate with any other trait measured and was distinguished by the lowest coefficient of variation $(8 \%)$.

Table 2. Mean values, coefficients of variations (CV) and correlation coefficients between volume, physiological and morphological traits. Red colour denotes a statistically significant correlation at a level of $\alpha=0.05$.

\begin{tabular}{|c|c|c|c|c|c|c|c|c|c|c|c|}
\hline Trait $^{1}$ & Mean & CV [\%] & $\mathrm{g}_{\mathrm{s}}$ & A & WUEi & E & $\mathbf{V}$ & LA & DM & SLA & SD \\
\hline$g_{s}$ & 291.66 & 25.97 & & & & & & & & & \\
\hline A & 13.97 & 13.87 & 0.39 & & & & & & & & \\
\hline WUEi & 5.51 & 22.27 & -0.75 & 0.06 & & & & & & & \\
\hline $\mathrm{E}$ & 3.15 & 12.36 & 0.85 & 0.37 & -0.79 & & & & & & \\
\hline V & 65.58 & 62.83 & -0.44 & 0.01 & 0.31 & -0.26 & & & & & \\
\hline LA & 32.87 & 28.75 & -0.32 & 0.16 & 0.17 & 0.03 & 0.53 & & & & \\
\hline DM & 0.27 & 28.42 & -0.23 & 0.16 & 0.04 & 0.11 & 0.35 & 0.91 & & & \\
\hline SLA & 125.37 & 10.98 & -0.36 & -0.23 & 0.35 & -0.37 & 0.39 & 0.21 & -0.15 & & \\
\hline SD & 734.85 & 21.66 & -0.48 & -0.20 & 0.16 & -0.27 & 0.25 & 0.34 & 0.39 & -0.05 & \\
\hline SL & 12.82 & 7.93 & 0.18 & 0.21 & -0.05 & 0.11 & -0.17 & -0.22 & -0.29 & 0.07 & -0.14 \\
\hline
\end{tabular}

${ }^{1} \mathrm{~g}_{\mathrm{s}}=$ stomatal conductance $\left(\mathrm{mmol} \mathrm{H}_{2} \mathrm{O} \mathrm{m}^{-2} \mathrm{~s}^{-1}\right) ; \mathrm{A}=$ photosynthetic rate $\left(\mu \mathrm{mol} \mathrm{CO} \mathrm{CO}^{-2} \mathrm{~s}^{-1}\right)$; WUEi = intrinsic water use efficiency $\left(\mathrm{mmol} \mathrm{CO} \mathrm{mmol}^{-1} \mathrm{H}_{2} \mathrm{O}\right) ; \mathrm{E}=$ evaporation rate $\left(\mathrm{mmol} \mathrm{H}_{2} \mathrm{O} \mathrm{m}^{-2} \mathrm{~s}^{-1}\right) ; \mathrm{V}=$ volume $\left(\mathrm{cm}^{3}\right)$; $\mathrm{LA}=$ leaf area $\left(\mathrm{cm}^{2}\right) ; \mathrm{DM}=$ dry mass $(\mathrm{g}) ; \mathrm{SLA}=$ specific leaf area $\left(\mathrm{cm}^{2} \mathrm{~g}^{-1}\right) ; \mathrm{SD}=$ stomatal density $\left(\right.$ no. $\left.\mathrm{mm}^{-2}\right)$; $\mathrm{SL}=$ stomatal length $(\mu \mathrm{m})$.

Results from the PCA are presented in Table 3 and Figure 1. The eigenvalues computed on the basis of the correlation matrix indicate the dominance of the first principal component, which explained $35.3 \%$ (eigenvalue $=3.5$ ) of the variance and was associated with $g_{s}, E, W U E i, V$, whereas the second PC was associated mainly with DM and LA and explained a further $22.4 \%$ (eigenvalue $=2.2$ ) of the variance.

Table 3. Pearson correlation coefficients between traits and the first two principal components (PC 1, PC 2); their coefficients of determination $\left(R^{2}\right)$.

\begin{tabular}{cccc}
\hline Trait $^{\mathbf{1}}$ & PC $\mathbf{1}$ & PC 2 & $\boldsymbol{R}^{\mathbf{2}}$ \\
\hline gs & 0.92 & 0.24 & 0.90 \\
DM & -0.42 & 0.85 & 0.90 \\
E & 0.76 & 0.56 & 0.89 \\
LA & -0.56 & 0.75 & 0.88 \\
WUEi & -0.73 & -0.33 & 0.64 \\
V & -0.65 & 0.26 & 0.49 \\
SD & -0.53 & 0.24 & 0.34 \\
SLA & -0.47 & -0.33 & 0.32 \\
A & 0.28 & 0.42 & 0.25 \\
SL & 0.29 & -0.25 & 0.15 \\
\hline
\end{tabular}

${ }^{1}$ The meaning of the trait abbreviations as in Table 2 footnote. 


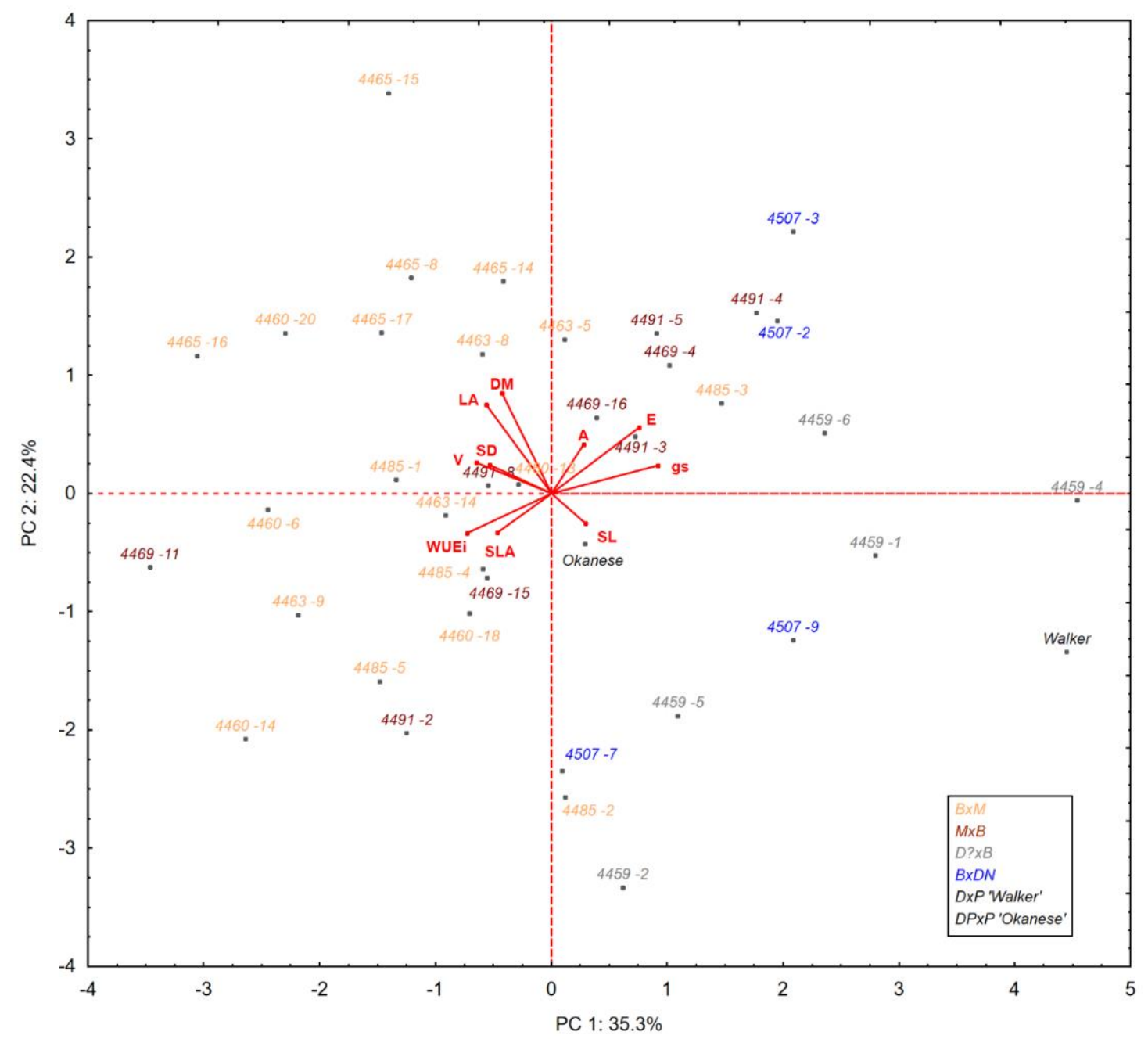

Figure 1. Principal component analysis (PCA) plot showing the multivariate variation among hybrid poplar clones for productivity, physiological, and morphological variables. Vectors indicate the direction and strength of each variable to the overall distribution. Colored clone codes correspond to the cross types represented in this study. The first two principal axes (PC 1, PC 2) explain $57.7 \%$ of the variance $(\lambda 1=3.5$ and $\lambda 2=2.2)$. The meaning of the trait abbreviations as in Table 2 footnote.

The location of the clones in the PCA ordination space shows many different patterns in physiological and morphological mechanisms (Figure 1). Generally, however, clones of $\mathrm{B} \times \mathrm{M}$ demonstrated higher WUE, productivity, denser stomata and larger leaf area, and higher dry mass than the other cross types. The reference clone Walker was distinguished by showing the lowest productivity and the highest stomatal conductance among all selected clones, while Okanese showed average values for most of the traits measured.

\subsection{Genetic Variation in Water Use Physiological and Morphological Characteristics Among Different Productivity Groups}

The mixed model analysis showed that the productivity group had a significant impact on most physiological characteristics (Table 4). Clone Okanese had the highest WUEi and A. Contrary to Okanese, the second reference clone, Walker, had the lowest WUEi and was characterized by the lowest A and significantly higher stomatal conductance among all tested clones (Figure 2). The results of the LSD test indicate that the average productivity group of clones was characterized by a higher WUEi than the group of clones in the low volume group. The remaining high productivity group of clones did not differ significantly from either the average or low productivity groups in any physiological 
traits except for WUEi, which was lower in comparison to the average productivity group (Figure 2). For morphological traits, the statistically significant effect $(\alpha \leq 0.05)$ of productivity was found for leaf area $(p=0.024)$ and stomatal density $(p=0.001)$. The highest stomatal density was estimated for the high and average productivity groups, while Walker, Okanese, and the low productivity group of clones created the second homogeneous group under LSD test (Figure 3). Furthermore, high and average productive clones were distinguished by the significantly larger leaf area in comparison to other groups of clones, while Okanese showed an intermediate LA. The least significant difference test also showed a significant difference between Walker and other groups of clones (except Okanese) for dry mass.

Analysis of variance components for random effects show that the genetic effect (combined effect of family and clone within family) explained only a small part of the overall variance $(\leq 11 \%)$ for all physiological traits (Figure 4a). For LA, SD, and SL, the genetic component explained 50\% or more variance (Figure $4 \mathrm{~b}$ ), while the genetic component for SLA explained $17 \%$ of the total variance. All variance component and heritability results are shown in Figure 4.
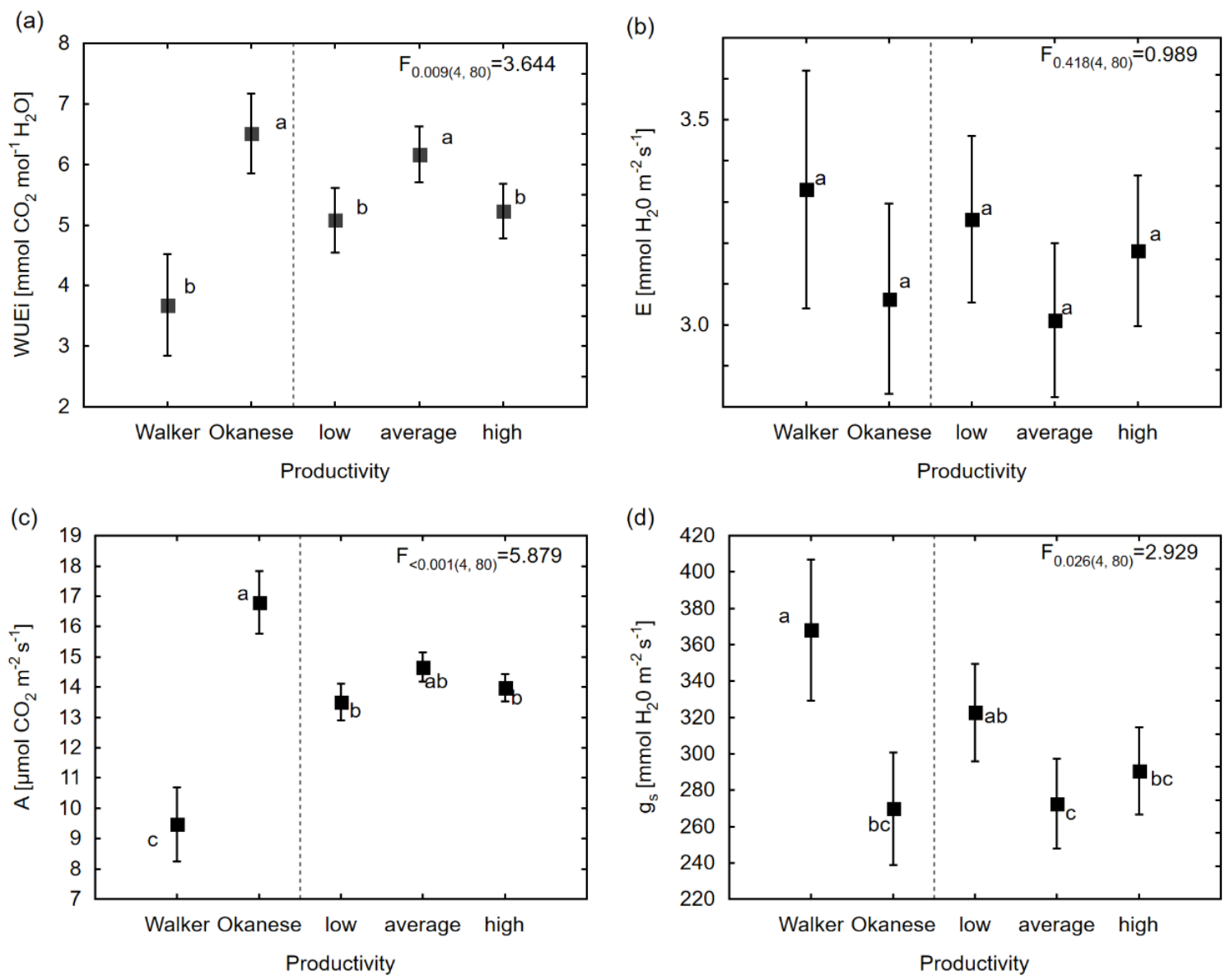

Figure 2. Estimated means for physiological traits in the linear mixed model and results of the least significant difference (LSD) test for: (a) WUEi; (b) E; (c) A; (d) $g_{s}$. The same letters signify homogeneous groups $(\alpha=0.05)$ in the post-hoc LSD test. The F-test values for productivity groups are shown with their $p$-values, followed by the degrees of freedom in brackets. The meaning of the trait abbreviations as in the Table 2 footnote. 
Table 4. Results of the linear mixed models for physiological and morphological traits. Variance components and their standard errors (SE) were estimated using the restricted maximum likelihood method. Level of significance of effects is denoted by bolded values for $0.1>p>0.05$, and bolded values accompanied with * for $p<0.05$.

\begin{tabular}{|c|c|c|c|c|c|c|c|c|}
\hline \multirow{3}{*}{ Trait $^{2}$} & & \multicolumn{5}{|c|}{ Random Effects } & Fixed Effect & Covariate \\
\hline & & \multicolumn{5}{|c|}{ Variance Components $\pm \mathrm{SE}^{1}$} & \multicolumn{2}{|c|}{$F$} \\
\hline & & $\sigma_{f}^{2}$ & $\sigma_{c}^{2}$ & $\sigma_{l f}^{2}$ & $\sigma_{l}^{2}$ & $\sigma_{e}^{2}$ & Productivity & VPD \\
\hline \multirow{4}{*}{ Physiological } & $\mathrm{g}_{\mathrm{s}}$ & $<0.001 \pm<0.001$ & $<0.001 \pm<0.001$ & $131.93 \pm 576.18$ & $1787.55 \pm 1620.79$ & $6596.62 \pm 907.41^{*}$ & $2.93 *$ & $149.79 *$ \\
\hline & $\mathrm{A}$ & $0.15 \pm 0.41$ & $0.51 \pm 0.59$ & $<0.001 \pm<0.001$ & $0.09 \pm 0.19$ & $5.44 \pm 0.74 *$ & $5.88 *$ & 103.85 * \\
\hline & E & $<0.001 \pm<0.001$ & $<0.001 \pm<0.001$ & $0.001 \pm 0.027$ & $0.108 \pm 0.097$ & $0.364 \pm 0.049 *$ & 0.99 & $24.39 *$ \\
\hline & $\mathrm{WUE}_{\mathrm{i}}$ & $0.10 \pm 0.20$ & $<0.001 \pm<0.001$ & $<0.001 \pm<0.001$ & $0.44 \pm 0.44$ & $3.21 \pm 0.39 *$ & $3.64 *$ & $30.88 *$ \\
\hline \multirow{6}{*}{ Morphological } & LA & $24.17 \pm 18.33$ & $23.31 \pm 9.38 *$ & $<0.001 \pm<0.001$ & $0.79 \pm 1.54$ & $39.11 \pm 5.58 *$ & 2.98 * & \multirow{6}{*}{ - } \\
\hline & DM & $2.11 \times 10^{-3} \pm 1.55 \times 10^{-3}$ & $9.56 \times 10^{-4} \pm 6.86 \times 10^{-4 *}$ & $1.16 \times 10^{-4} \pm 3.78 \times 10^{-4}$ & $<0.001 \pm<0.001$ & $4.61 \times 10^{-4} \pm 7.29 \times 10^{-4 *}$ & 1.92 & \\
\hline & SLA & $1.92 \pm 32.43$ & $77.98 \pm 49.57$ & $15.72 \pm 34.62$ & $<0.001 \pm<0.001$ & $379.18 \pm 60.74 *$ & 0.75 & \\
\hline & SD & $6855.76 \pm 4833.98$ & $3758.52 \pm 1905.00 *$ & $<0.001 \pm<0.001$ & $<0.001 \pm<0.001$ & $10425.4 \pm 1531.30$ & $5.07^{*}$ & \\
\hline & SL & $0.52 \pm 0.38$ & $0.23 \pm 0.11 *$ & $0.19 \pm 0.11 *$ & $<0.001 \pm<0.001$ & $0.56 \pm 0.1 *$ & 1.42 & \\
\hline & $\mathrm{V}$ & $<0.001 \pm<0.001$ & $737.62 \pm 217.91 *$ & $22.18 \pm 54.07$ & $7.35 \pm 23.98$ & $640.03 \pm 100.23 *$ & $8.83^{*}$ & \\
\hline
\end{tabular}

${ }^{1} \sigma_{f}^{2}$-variance of family effects, $\sigma_{c}^{2}$-variance of clonal within family effects, $\sigma_{l}^{2}$-variance of family-by-block interaction effects, $\sigma_{l}^{2}$-variance of block effects, $\sigma_{e}^{2}$-variance of residual

effects. ${ }^{2}$ The meaning of the trait abbreviations as in Table 2 footnote. VPD, vapor pressure deficit. 
(a)

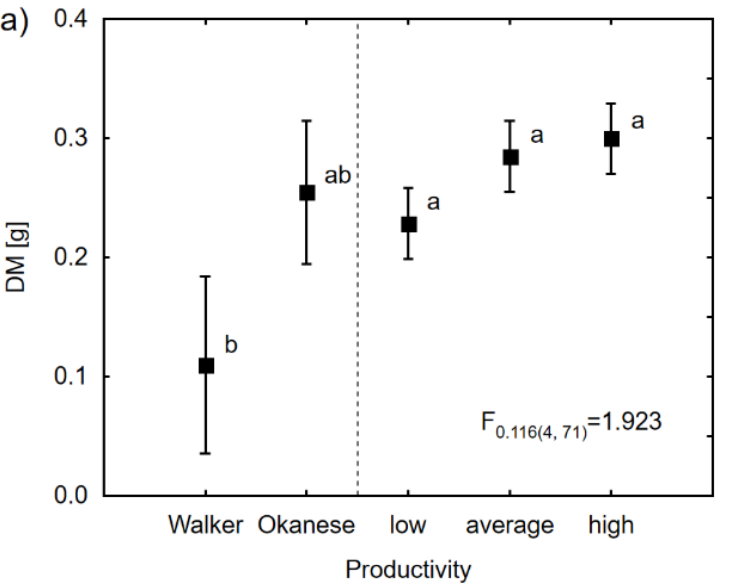

(c)
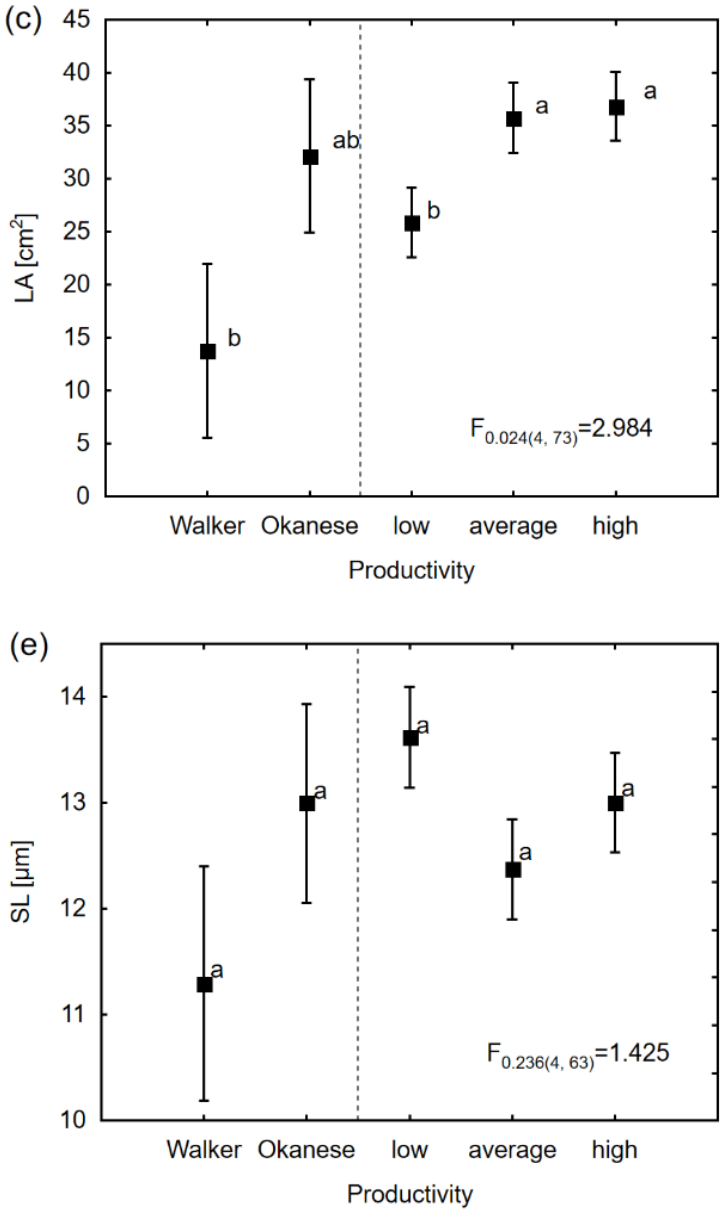
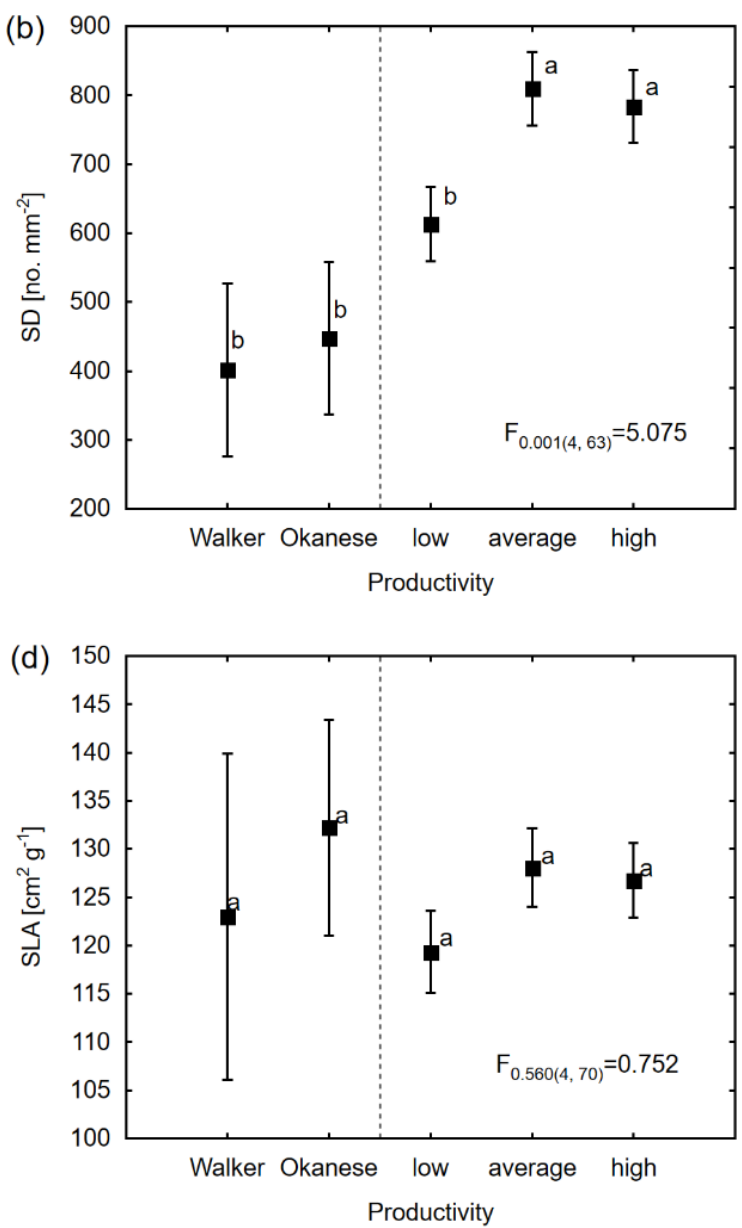

Figure 3. Estimated means for morphological traits in the linear mixed model and results of the LSD test for: (a) DM; (b) SD; (c) LA; (d) SLA; (e) SL. The same letters signify homogeneous groups $(\alpha=0.05)$ in the post-hoc LSD test. The F-test values for productivity groups are shown with their $p$-values, followed by the degrees of freedom in brackets. The meaning of the trait abbreviations as in the Table 2 footnote. 
(a)

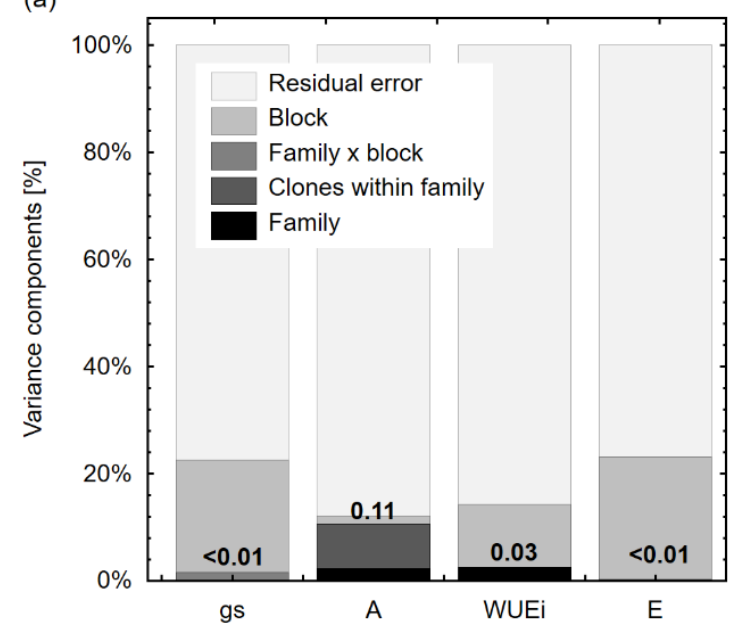

(b)

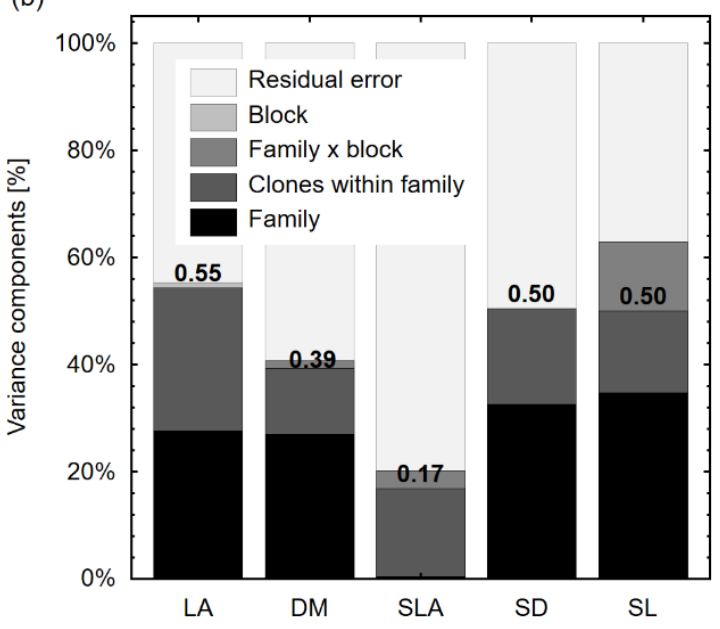

Figure 4. Variance component analysis for random effects in the linear mixed model. Variance components were estimated using the restricted maximum likelihood (REML) method for (a) physiological traits (gs, A, WUEi, E) and (b) morphological traits (LA, DM, SLA, DS, SL) of 10 -year-old hybrid poplars. Broad sense heritabilities are shown as numerical values above the bars for the combined effect of family and clone within family (genetic effect). The meaning of the trait abbreviations as in Table 2 footnote.

\section{Discussion}

As temperatures warm and precipitation patterns shift [1,36], the deployment of better adapted trees to a changing climate, with high productivity and WUE, will be essential for sustainable and cost-effective forest/land management. Hybrid poplars are particularly well suited to such rapidly changing needs with their shortened production cycles (compared to native forests in boreal regions), serving as a partial remedy for the loss of stability of forest ecosystems in conditions of rapidly progressing climate change [37]. Given the flexibility of moving from a rotation of 60-70 years in native aspen stands [38] to 18-25 years with hybrid poplars, the advantages of being able to adjust clones to accommodate a quickly changing climate is possible and necessary. Our experiment was carried out in a relatively xeric habitat ( $432 \mathrm{~mm}$ annual precipitation) in northern Alberta, and the results suggest that the intrinsic variation among clones in physiological and morphological traits related to WUE provides a foundation for selection of productive and water use efficient genotypes (to some extent) for regions with increasing drought.

Productivity is the primary trait of interest in most tree breeding programs, and often defined as an adaptation to water stress conditions [1]. In our study, productivity was positively correlated with LA, DM, and SLA, which combines both morphological characteristics (i.e., LA and DM), as represented by the light-capturing area deployed per dry mass allocated [39]. A high SLA indicates the occurrence of thinner leaves, which are less costly to produce and maintain [40] and, due to the associated rapid leaf production, allows for an efficient capture of solar energy [41]. Thus, genotypes with a high SLA have a shorter investment return rate and greater potential for faster growth [42]. As revealed in our study, SLA was also positively correlated with WUEi and negatively correlated with transpiration and stomatal conductance, which shows the potential of this trait for selecting productive and water use efficient genotypes. In addition, however, SLA was also characterized by a rather low discriminative power and broad sense heritability, indicating that it is not a stand-alone trait for selection, thus SLA should be combined with additional traits of interest in a breeding program.

Several studies have suggested a role for regulation of stomatal aperture in acclimation and adaptation to water stress and temperature [2]. Stomatal conductance, which provides a relative measure of how open or closed the stomata are, was the only physiological trait that was correlated with productivity. Higher stomatal conductance to water usually increases $\mathrm{CO}_{2}$ diffusion into the 
leaf, and hence, incorporation into biomass [43], which was reflected in the positive correlation found between $\mathrm{g}_{\mathrm{s}}$ and $\mathrm{A}$. The negative correlation between stomatal conductance and productivity observed in our study seems, however, to be associated with another phenomenon. Water deficit during midday hours, in which measurements were carried out, may initiate a "defence reaction" in trees against water loss by stomatal closure. We hypothesize that such results may signify more efficient stomatal control among genotypes with better productivity. Nonetheless, in this aspect, more extensive investigation is necessary to evaluate possible diurnal and seasonal differences, as our results are based on a single measurement during the day. Such repeatable measurements would also likely allow us to mitigate another limitation of our study, indicated by the large component of residual error variance as compared to the total variance for stomatal conductance and other physiological traits.

The reported values of stomatal conductance for poplars have been shown to be as high as $1000 \mathrm{mmol} \mathrm{m}^{-2} \mathrm{~s}^{-1}[44,45]$, which is usually related to low WUE [11,46], and generally reflects the status of poplars as phreatophytes and riparian species that typically grow on moist alluvial soils after floods or other disturbances [20,47-49]. Our study, carried out in a more xeric habitat of north-central Alberta, revealed that stomatal conductance indeed strongly affects intrinsic WUE (negative correlation, Table 2, Figure 1), but the mean values for all tested genotypes $\left(296 \mathrm{mmol} \mathrm{m}^{-2} \mathrm{~s}^{-1}\right)$ were much lower than reported, which shows adaptive plasticity of our studied clones to water stress conditions. A similar conclusion was also drawn by Hetherington and Woodward [46], who suggest that low values of $g_{s}$ may occur in water-limited environments, where small reductions in stomatal conductance significantly increase WUE.

With respect to morphological characteristics, our investigation showed that the average stomatal density on the abaxial side of the leaves was 735 no. per $\mathrm{mm}^{2}$, across all hybrid poplar cross types and clones (range from 401, for Walker to 1091, for $\mathrm{M} \times \mathrm{B}$ 4491-5). These values are among the highest recorded densities for poplar species and their hybrids [20,50]. In addition, the average length of stomatal guard cells $(12.82 \mu \mathrm{m})$ was significantly shorter in comparison to those of similar or other species hybrids adapted to grow in xeric and moderate environments $[11,20,25,26,32]$.

Leaves growing under water deficit usually develop smaller and more densely distributed stomata [2]. These modifications in morphological characteristics make leaves able to reduce transpiration with a quicker onset of stomatal regulation [51,52]. Thus, most of the clones tested in our study showed adaptive acclimatization to the region of deployment. Surprisingly, the reference clone Walker, widely planted in the Canadian prairies, distinguished itself among the tested clones by showing the lowest stomatal densities, which in combination with the highest stomatal conductance and transpiration rate, and the lowest net assimilation and productivity, resulted in it being ranked the lowest in terms of adaptive capacity to the predicted direction of climate change (Figure 1). Based on the discussion above, it seems that Walker should be reconsidered for operational deployment in the future, given an anticipated increase in water deficit. In this aspect, our results contradict the previous findings by Arshad et al. [21] Desrochers et al. [53], and Arango-Velez et al. [54], who placed Walker in the top ranking with respect to the impact of drought stress on water content and growth among other hybrid poplars currently grown in the prairies and Alberta. One consideration to note, Walker was used as a reference clone in this study to measure against new genetic material, where it was outcompeted at an early stage of stand development [29] and therefore, overshadowed, performing even less well given that the new clones were far superior in growth parameters.

It is known that stomatal density and stomatal function can be influenced by environmental conditions during the development of leaf length [20]. High stomatal densities and small stomata may not accurately reflect stomatal sizes and densities occurring in these genotypes when grown in different conditions $[20,46]$, which points to variable phenotypic plasticity among genotypes in these morphological characteristics. Although we did not study morphological characteristics between clones in different environments, the large amount of explained genetic variation for stomatal density and stomatal guard cell length implies that these morphological characteristics are under relatively strong genetic control (Table 1, Figure 3). The largest component of variance is explained by the family 
effect, which in our study can be treated to some extent as a proxy for cross types. As was shown on the PCA biplot (Figure 1) clones of the $\mathrm{B} \times \mathrm{M}$ cross were characterized by the highest stomatal density and productivity, while Walker, as well as other clones, whose parents came from the Aigeiros section (P. nigra, P. deltoides), had less dense stomata and visibly different physiological and morphological strategies. Our findings generally correspond to previous research outcomes that $P$. maximowiczii hybridized with P. balsamifera demonstrate good performance in cooler Canadian climates [55].

It appears that in the face of climate change, all efforts related to increasing WUE in selection programs need to be combined with the intended cultural practices designed to improve WUE at the plantation level. This set of silvicultural techniques often include: site preparation prior to planting, weed control during the establishment phase of the plantation [56,57], fertilization, use of mycorrhizae, thinning, and plantation density [58]. Most of these techniques are designed to reduce competition for soil and water resources and improve root growth conditions and/or water uptake. The plantation density appears to be important, in particular, having a permanent effect for the life of the plantation. In northern Alberta, where rotation ages on plantations are between 18-25 years, and the trees are often grown at a relatively tight spacing (e.g., $3.0 \times 3.0 \mathrm{~m}$ spacing or less), the root development and growth parameters can be enhanced by the choice of a lower stand density. Given the strong influence of spacing on all selective traits, water interception, and soil water availability, extrapolations cannot be made without further research efforts related to tree density and other cultural practices combined with appropriate clone selection.

\section{Conclusions}

Results of our study reveal that most of the clones showed an adaptive capacity to acclimatize to the region of deployment being tested. The variation among clones in physiological and morphological characteristics related to WUE at a leaf level suggests the possibility of achieving genetic gain through selection of these traits. Among the studied traits, stomatal density in combination with their size and specific leaf area appear key and heritable factors that assure a fast reaction of stomata when faced with a water deficit. Thus, it seems that selection and tree breeding for adapting to climate change in the region of our investigation could rely on highly productive genotypes with dense, small stomata and a larger ratio of leaf area to dry mass.

With respect to cross types, it appears that hybrid crosses of P. balsamifera and P. maximowiczii species show a slightly better adaptive potential to the area of our study than the other tested cross types. Our findings further suggest that Walker, widely planted across the Canadian prairies, had an inferior adaptive capacity to the predicted direction of climate change in comparison to new genotypes tested in this study. Therefore, it seems reasonable to consider removal of this clone from operational deployment in the coming years.

For physiological traits, the estimated low genetic effect, low heritabilities, and high residual effect impose a severe limitation on the use of gas exchange measurements under field conditions for tree improvement programs selecting for drought resistance. It is thus necessary to fill the gap in measurement methodology to better understand the underlying processes leading to differential responses. Further research efforts need to improve sampling procedures, repeatability of measurements, and also take into consideration other factors that influence the unexplained variation, thereby limiting, as much as possible, residual error.

Author Contributions: Conceptualization, M.N. and B.R.T.; methodology, M.N.; formal analysis, M.N.; investigation, M.N. and Y.H.; writing—original draft preparation, M.N.; writing一review and editing, B.R.T., Y.H., and M.N.

Funding: This manuscript was developed under a Scholarship grant to Marzena Niemczyk within a Scholarship Fund of the Forest Research Institute, pursuant to the decision of the Head of the Institute dated 20.10.2017 (based on an Agreement concluded on 23.10.2017 with a further Annex no. 1 of 2, May, 2018) and start-up funds of Barb R. Thomas. 
Acknowledgments: The authors wish to express their gratitude to Pierre Périnet (QC) who conducted the breeding, and Morgan Randall (University of Alberta) and David Kamelchuk (Alberta-Pacific Forest Industries Inc.) for their contributions to field data collection.

Conflicts of Interest: The authors declare no conflicts of interest. The funders had no role in the design of the study; in the collection, analyses, or interpretation of data; in the writing of the manuscript; or in the decision to publish the results.

\section{References}

1. Moran, E.; Lauder, J.; Musser, C.; Stathos, A.; Shu, M. The genetics of drought tolerance in conifers. New Phytol. 2017, 216, 1034-1048. [CrossRef]

2. Bacelar, E.L.V.A.; Moutinho-Pereira, J.M.; Gonçalves, B.M.C.; Brito, C.V.Q.; Gomes-Laranjo, J.; Ferreira, H.M.F.; Correia, C.M. Water use strategies of plants under drought conditions. In Plant Responses to Drought Stress: From Morphological to Molecular Features; Aroca, R., Ed.; Springer: Berlin/Heidelberg, Germany, 2012; pp. 145-170.

3. Hogg, E.H.; Michaelian, M.; Hook, T.I.; Undershultz, M.E. Recent climatic drying leads to age-independent growth reductions of white spruce stands in western Canada. Glob. Chang. Biol. 2017, 23, 5297-5308. [CrossRef] [PubMed]

4. Wang, Y.; Hogg, E.H.; Price, D.T.; Edwards, J.; Williamson, T. Past and projected future changes in moisture conditions in the Canadian boreal forest. Houst. Chron. 2014, 90, 678-691. [CrossRef]

5. Richardson, J.; Isebrands, J.G.; Ball, J.B. Ecology and physiology of poplars and willows. In Poplars and Willows: Trees for Society and the Environment; Isebrands, J.G., Richardson, J., Eds.; CAB International and FAO: Rome, Italy, 2014; pp. 92-123.

6. Żelawski, W. Gaseous exchange and water relations. In Topole populus, L.; Białobok, S., Ed.; Państwowe Wydawnictwo Naukowe: Warsaw, Poland, 1973; pp. 204-235.

7. Stanton, B.J.; Serapiglia, M.J.; Smart, L.B. The domestication and conservation of Populus and Salix genetic resources. In Poplars and Willows: Trees for Society and the Environment; Isebrands, J.G., Richardson, J., Eds.; CAB International and FAO: Rome, Italy, 2014; pp. 124-199.

8. Stettler, R.F.; Zsuffa, L.; Wu, R. The role of hybridization in the genetic manipulation of Populus. In Biology of Populus; Stettler, R.F., Bradshaw, H.D., Heilmann, P.E., Hinckley, T.M., Eds.; NRC Research Press: Ottawa, ON, Canada, 1996; pp. 87-112.

9. Hu, Y.; Thomas, B.R. Hormones and heterosis in hybrid balsam poplar (Populus balsamifera L.). Forests 2019, 10, 143. [CrossRef]

10. Goff, S.A. A unifying theory for general multigenic heterosis: Energy efficiency, protein metabolism, and implications for molecular breeding. New Phytol. 2011, 189, 923-937. [CrossRef] [PubMed]

11. Blake, T.J.; Tschaplinski, T.J.; Eastham, A. Stomatal control of water use efficiency in poplar clones and hybrids. Can. J. Bot. 1984, 62, 1344-1351. [CrossRef]

12. Condon, A.G.; Richards, R.A.; Rebetzke, G.J.; Farquhar, G.D. Breeding for high water-use efficiency. J. Exp. Bot. 2004, 55, 2447-2460. [CrossRef] [PubMed]

13. Medrano, H.; Tomás, M.; Martorell, S.; Flexas, J.; Hernández, E.; Rosselló, J.; Pou, A.; Escalona, J.M.; Bota, J. From leaf to whole-plant water use efficiency (WUE) in complex canopies: Limitations of leaf WUE as a selection target. Crop J. 2015, 3, 220-228. [CrossRef]

14. Tschaplinski, T.J.; Blake, T.J. Water-stress tolerance and late-season organic solute accumulation in hybrid poplar. Can. J. Bot. 1989, 67, 1681-1688. [CrossRef]

15. Tschaplinski, T.J.; Tuskan, G.A.; Gunderson, C.A. Water-stress tolerance of black cottonwood and eastern cottonwood clones and four of their hybrid progeny. I. Growth, water relations and gas exchange. Can. J. Res. 1994, 24, 364-371. [CrossRef]

16. Marron, N.; Villar, M.; Dreyer, E.; Delay, D.; Boudouresque, E.; Petit, J.M.; Delmotte, F.M.; Guehl, J.M.; Brignolas, F. Diversity of leaf traits related to productivity in 31 Populus deltoides $\mathrm{x}$ Populus nigra clones. Tree Physiol. 2005, 25, 425-435. [CrossRef] [PubMed]

17. Thomas, B.R.; Macdonald, S.E.; Dancik, B.P. Variance components, heritabilities and gain estimates for growth chamber and field performance of Populus tremuloides: Gas exchange parameters. Silvae Genet. 1997, $46,309-317$. 
18. Condon, A.G.; Richards, R.A.; Rebetzke, G.J.; Farquhar, G.D. Improving intrinsic water-use efficiency and crop yield. Crop Sci. 2002, 42, 122-131. [CrossRef] [PubMed]

19. Al Afas, N.; Marron, N.; Ceulemans, R. Clonal variation in stomatal characteristics related to biomass production of 12 poplar (Populus) clones in a short rotation coppice culture. Environ. Exp. Bot. 2006, 58, 279-286. [CrossRef]

20. Pearce, D.W.; Millard, S.; Bray, D.F.; Rood, S.B. Stomatal characteristics of riparian poplar species in a semi-arid environment. Tree Physiol. 2006, 26, 211-218. [CrossRef]

21. Arshad, M.; Biswas, K.; Bisgrove, S.; Schroeder, W.R.; Thomas, B.R.; Mansfield, S.D.; Mattsson, J.; Plant, A. Differences in drought resistance in nine North American hybrid poplars. Trees 2019, 33, 1111-1128. [CrossRef]

22. Condon, A.G.; Farquhar, G.D.; Richards, R.A. Genotypic variation in carbon isotope discrimination and transpiration efficiency in wheat. Leaf gas exchange and whole plant studies. Aust. J. Plant Physiol. 1990, 17, 9-22. [CrossRef]

23. Ceulemans, R. Genetic Variation in Functional and Structural Productivity Determinants in Poplar; Thesis Publishers: Amsterdam, The Netherlands, 1990; p. 99.

24. Brendel, O.; Pot, D.; Plomion, C.; Rozenberg, P.; Guehl, J.-M. Genetic parameters and QTL analysis of $\delta^{13} \mathrm{C}$ and ring width in maritime pine. Plant Cell Environ. 2002, 25, 945-953. [CrossRef]

25. Pallardy, S.G.; Kozlowski, T.T. Frequency and length of stomata of 21 Populus clones. Can. J. Bot. 1979, 57, 2519-2523. [CrossRef]

26. Ceulemans, R.; Impens, I.; Steenackers, V. Stomatal and anatomical leaf characteristics of 10 Populus clones. Can. J. Bot. 1984, 62, 513-518. [CrossRef]

27. Dunlap, J.M.; Stettler, R.F. Variation in leaf epidermal and stomatal traits of Populus trichocarpa from two transects across the Washington Cascades. Can. J. Bot. 2001, 7, 528-536. [CrossRef]

28. Alberta Climate Information Service. Available online: https://agriculture.alberta.ca/acis/ (accessed on 1 October 2019).

29. Niemczyk, M.; Thomas, B.R. Multi-trait selection of hybrid poplars for northern climates. Ann. For. Sci. under review.

30. Lindquist, C.H.; Cram, W.H.; Howe, J.A.G. Walker Poplar. Can. J. Plant Sci. 1977, 57, 1019. [CrossRef]

31. Schroeder, W.; Soolanayakanahally, R.; Lindquist, C. Okanese poplar. Can. J. For. Res. 2013, 93, 1281-1283. [CrossRef]

32. Ceulemans, R.; van Praet, L.; Jiang, X.N. Effects of $\mathrm{CO}_{2}$ enrichment, leaf position and clone on stomatal index and epidermal cell density in poplar (Populus). New Phytol. 1995, 131, 99-107. [CrossRef]

33. Fetter, K.C.; Eberhardt, S.; Barclay, R.S.; Wing, S.; Keller, S.R. StomataCounter: A neural network for automatic stomata identification and counting. New Phytol. 2019, 223, 1671-1681. [CrossRef]

34. Searle, S.R.; Casella, G.; McCulloch, C.E. Variance Components; John Wiley and Sons Inc.: New York, NY, USA, 1992; p. 501.

35. Zamudio, F.; Wolfinger, R.; Stanton, B.; Guerra, F. The use of linear mixed model theory for the genetic analysis of repeated measures from clonal tests of forest trees. I. A focus on spatially repeated data. Tree Genet. Genomes 2008, 4, 299-313. [CrossRef]

36. Mbogga, M.S.; Hamann, A.; Wang, T. Historical and projected climate data for natural resource management in western Canada. Agric. Meteorol. 2009, 149, 881-890. [CrossRef]

37. Niemczyk, M.; Przybysz, P.; Przybysz, K.; Kaliszewski, A.; Wojda, T.; Liesebach, M. Productivity, growth patterns, and cellulosic pulp properties of hybrid aspen clones. Forests 2019, 10, 450. [CrossRef]

38. Peterson, E.B.; Peterson, N.M. Ecology, Management, and Use of Aspen and Balsam Poplar in the Prairie Provinces, Canada; Northern Forestry Center: Edmonton, AB, Canada, 1992; 252p.

39. Hamilton, M.A.; Murray, B.R.; Cadotte, M.W.; Hose, G.C.; Baker, A.C.; Harris, C.J.; Licari, D. Life-history correlates of plant invasiveness at regional and continental scales. Ecol. Lett. 2005, 8, 1066-1074. [CrossRef]

40. Lee, D.W.; Graham, R. Leaf optical properties of rainforest sun and extreme shade plants. Am. J. Bot. 1986, 73, 1100-1108. [CrossRef]

41. Grotkopp, E.; Rejmánek, M. High seedling relative growth rate and specific leaf area are traits of invasive species: Phylogenetically independent contrasts of woody angiosperms. Am. J. Bot. 2007, 94, 526-532. [CrossRef] [PubMed]

42. Lake, J.C.; Leishman, M.R. Invasion success of exotic plants in natural ecosystems: The role of disturbance, plant attributes and freedom from herbivores. Biol. Conserv. 2004, 117, 215-226. [CrossRef] 
43. Erice, G.; Sanz-Sáez, A.; Aranjuelo, I.; Irigoyen, J.J.; Sánchez-Díaz, M. Future Environmental Conditions will Limit Yield in $\mathrm{N}_{2}$ Fixing Alfalfa. In Plant Responses to Drought Stress: From Morphological to Molecular Features; Aroca, R., Ed.; Springer: Berlin/Heidelberg, Germany, 2012; pp. 363-382.

44. Foster, J.R.; Smith, W.K. Stomatal conductance patterns and environment in high elevation phreatophytes of Wyoming. Can. J. Bot. 1991, 69, 647-655. [CrossRef]

45. Sparks, J.P.; Black, R.A. Regulation of water loss in populations of Populus trichocarpa: The role of stomatal control in preventing xylem cavitation. Tree Physiol. 1999, 19, 453-459. [CrossRef] [PubMed]

46. Hetherington, A.M.; Woodward, F.I. The role of stomata in sensing and driving environmental change. Nature 2003, 424, 901-908. [CrossRef] [PubMed]

47. Bugała, W. Systematyka i zmienność. In Topole populus L.; Białobok, S., Ed.; Państwowe Wydawnictwo Naukowe: Warsaw, Poland, 1973; pp. 9-136.

48. Braatne, J.H.; Hinckley, T.M.; Stettler, R.F. Influence of soil water on the physiological and morphological components of plant water balance in Populus trichocarpa, Populus deltoides and their $\mathrm{F}_{1}$ hybrids. Tree Physiol. 1992, 11, 325-339. [CrossRef]

49. Rood, S.B.; Mahoney, J.M. River damming and riparian cottonwoods along the Marias River, Montana. Rivers 1995, 5, 195-207. [CrossRef]

50. Royer, D.L. Stomatal density and stomatal index as indicators of paleoatmospheric $\mathrm{CO}_{2}$ concentration. Rev. Palaeobot. Palynol. 2001, 114, 1-28. [CrossRef]

51. Larcher, L.; Hara-Nishimura, I.; Sternberg, L. Effects of stomatal density and leaf water content on the ${ }^{18} \mathrm{O}$ enrichment of leaf water. New Phytol. 2015, 206, 141-151. [CrossRef]

52. Aasamaa, K.; Sõber, A.; Rahi, M. Leaf anatomical characteristics associated with shoot hydraulic conductance, stomatal conductance and stomatal sensitivity to changes of leaf water status in temperate deciduous trees. Funct. Plant Biol. 2001, 28, 765-774. [CrossRef]

53. Desrochers, A.; van den Driessche, R.; Thomas, B.R. The interaction between nitrogen source, soil pH, and drought in the growth and physiology of three poplar clones. Botany 2007, 85, 1046-1057. [CrossRef]

54. Arango-Velez, A.; Zwiazek, J.J.; Thomas, B.R.; Tyree, M.T. Stomatal factors and vulnerability of stem xylem to cavitation in poplars. Physiol. Plant. 2011, 143, 154-165. [CrossRef] [PubMed]

55. Pliura, A.; Suchockas, V.; Sarsekova, D.; Gudynaite, V. Genotypic variation and heritability of growth and adaptive traits, and adaptation of young poplar hybrids at northern margins of natural distribution of Populus nigra in Europe. Biomass Bioenergy 2014, 70, 513-529. [CrossRef]

56. Henkel-Johnson, D.; Macdonald, S.E.; Bork, E.W.; Thomas, B.R. Influence of weed composition, abundance, and spatial proximity on growth in young hybrid poplar plantations. Ecol. Manag. 2016, 362, 55-68. [CrossRef]

57. Goehing, J.; Thomas, B.R.; Macdonald, S.E.; Bork, E.W. Effects of alternative establishment systems on resource availability, understorey composition and tree performance in juvenile hybrid poplar plantations. Forestry 2017, 90, 515-529. [CrossRef]

58. Jiang, Z.-H.; Wang, X.-Q.; Fei, B.-H.; Ren, H.-Q.; Liu, X.-E. Effect of stand and tree attributes on growth and wood quality characteristics from a spacing trial with Popul Xiaohei. Ann. Sci. 2007, 64, 807-814. [CrossRef]

(C) 2019 by the authors. Licensee MDPI, Basel, Switzerland. This article is an open access article distributed under the terms and conditions of the Creative Commons Attribution (CC BY) license (http://creativecommons.org/licenses/by/4.0/). 